\title{
In sacco nutrient degradability of silage containing intact and defatted black soldier fly (Hermetia illucens) larvae
}

\author{
R. Mulianda ${ }^{1}$, A. Sofyan ${ }^{2}$, H. Herdian ${ }^{2}$, E.B. Laconi ${ }^{3}$, M. Ridla ${ }^{3}$, \\ W.W. Wardani ${ }^{4}$ and A. Jayanegara ${ }^{3, *}$ \\ ${ }^{1}$ Study Program of Nutrition and Feed Science, Graduate School of IPB University, Bogor, 16680, \\ Indonesia \\ ${ }^{2}$ Research Group of BioFeed-Additive Technology, Research Division for Natural Product Technology \\ (BPTBA), Indonesian Institute of Sciences (LIPI), Gading, Playen, Gunungkidul, DI. Yogyakarta, \\ Indonesia \\ ${ }^{3}$ Department of Nutrition and Feed Technology, Faculty of Animal Science, IPB University, \\ Bogor 16680, Indonesia \\ ${ }^{4}$ Nutricell R\&D, Cibis Nine $12^{\text {th }}$ Floor Unit, Jakarta 12560, Indonesia \\ *Corresponding E-mail: anuraga.jayanegara@gmail.com
}

Received December 13, 2020; Accepted June 13, 2021

\begin{abstract}
ABSTRAK
Penelitian ini bertujuan untuk untuk mengevaluasi degradabilitas nutrien secara in sacco dari silase ransum komplit (SRK) yang mengandung larva lalat tentara hitam utuh dan yang dihilangkan lemaknya. Penelitian dilakukan dengan menggunakan empat perlakuan dan enam ulangan. Perlakuan terdiri dari SRK kontrol tanpa larva BSF (R1), 20\% larva BSF utuh $+80 \%$ SRK (R2), 20\% larva BSF yang dihilangkan lemaknya secara kimiawi $+80 \%$ SRK (R3), dan $20 \%$ larva BSF yang dihilangkan lemaknya secara mekanis $+80 \%$ SRK (R4). Sampel dianalisis komposisi kimianya, dimasukkan ke dalam kantong poliester, dan diinkubasi dalam rumen secara in sacco selama 72 jam. Hasil penelitian menunjukkan bahwa degradasi bahan kering (DBK) terendah terdapat pada R1 dibandingkan perlakuan lainnya $(\mathrm{p}<0,05)$, sedangkan DBK tertinggi terdapat pada R2 $(\mathrm{p}<0,05)$. Degradasi bahan organik tertinggi terdapat pada R2 dibandingkan dengan R1, R3 dan R4 $(p<0,05)$. Penambahan larva BSF ke dalam SRK meningkatkan degradabilitas protein kasar $(\mathrm{p}<0,05)$. Dapat disimpulkan bahwa penggunaan larva BSF, baik yang utuh maupun yang telah dihilangkan lemaknya ke dalam SRK tidak memberikan pengaruh negatif terhadap profil nutrien dan menunjukkan nilai degradasi nutrien yang baik di dalam rumen.
\end{abstract}

Kata kunci: in sacco, Silase, Magot, Rumen, Nutrien

\begin{abstract}
This study aimed to evaluate the in sacco nutrient degradability of total mixed ration (TMR) silage containing intact and defatted black soldier fly (BSF) larvae. The study evaluated four dietary treatments and six replications. The treatments consisted of control TMR silage without BSF larvae
\end{abstract}


(R1), $20 \%$ intact BSF larvae $+80 \%$ TMR silage (R2), $20 \%$ chemically defatted BSF larvae $+80 \%$ TMR silage (R3), and 20\% mechanically defatted BSF larvae $+80 \%$ TMR silage (R4). Samples were placed in polyester bags and incubated in the rumen in sacco up to $72 \mathrm{~h}$. Nutrient degradability was evaluated for each time point interval. Results revealed that the lowest dry matter degradability (DMD) was found in R1 compared to all treatments $(\mathrm{p}<0.05)$, while the highest DMD was found in R2 ( $\mathrm{p}<$ 0.05 ). The highest organic matter degradability was found in R2 compared to R1, R3 and R4 (p < $0.05)$. Addition of BSF larvae to TMR silage increased the crude protein degradability $(\mathrm{p}<0.05)$. In conclusion, inclusion of both intact and defatted BSF larvae into TMR silage did not have any adverse effects on nutrient profiles and showed a good nutrient degradation values in the rumen.

Keywords: in sacco, Silage, Maggot, Rumen, Nutrient

\section{INTRODUCTION}

Animal foods, such as milk and meat, are the key sources of human nutrition. Provision of quality feed to livestock in the right proportion is important since feed as a source of nutrient has a direct impact on livestock productivity. Attempts to enhance livestock productivity usually faces an obstacle due to the tight competition for feed resources. In addition, productivity is also constrained by the high cost of feed. Novel feed ingredients are being explored continuously in order to obtain affordable, easy-to-source and nutrient-rich alternatives. Among these alternative feeds are insects and their nutritional composition are generally rich in protein (Van Huis, 2013; Sogari et al., 2019).

Among the insects, black soldier fly (BSF) larvae or known as maggots have been considered as alternatives to expensive protein sources, and they typically contain more than $40 \%$ of crude protein (Barragan-Fonseca et al., 2017). BSF has the capacity to convert organic waste into high protein feed. To date, maggots have been fed as alterative protein sources primarily to monogastric animals such as poultry, i.e., broiler chickens and laying hens (Zotte et al., 2019; Biasato et al., 2020). Only few studies, however, have evaluated the use of maggots as feed ingredients in the diets of ruminants (Mulianda et al., 2020). Furthermore, BSF larvae were able to be used as feed ingredients for ruminants because they have high protein contents and provide high proportion of rumen undegradable or bypass protein (Jayanegara et al., 2017a; 2017b).
On the other hand, BSF larvae has a fairly high fat content ranging from 30.1-34.3\% (Shumo et al., 2019). This high fat content limits the use of BSF larvae to be given to chickens, pigs and fish, which can only partially replace the protein source commonly fed to these animals (Fonseca et al., 2017). In ruminants, high fat content may negatively affect the rumen fermentation process, decrease nutrient digestibility, and reduce energy intake (Morris et al., 2020). Removal of fat either partially of completely from the BSF larvae is expected to increase the nutrient utilization for ruminants. The objective of this experiment was to determine the in sacco degradability of total mixed ration (TMR) silage containing intact and defatted BSF larvae.

\section{MATERIALS AND METHODS}

\section{Experimental Animal}

This study used two male Ongole cattle with a $3-\mathrm{cm}$ diameter rumen fistula. The cattle were given an ad libitum basal feed and cared for according to the animal welfare standards of Indonesian Research Center for Animal Production (IRCAP).

\section{Sample Preparation and Treatment}

Fifteen-day-old BSF larvae were collected from PT Biocycle, Bogor. BSF larvae were defatted mechanically and chemically in the Laboratory of Feed Science and Technology, Faculty of Animal Science, IPB University. The dead larvae were dried in an oven at $50^{\circ} \mathrm{C}$ for 24 hours. Mechanical fat removal was performed by 
Table 1. Nutrient Composition of the Experimental Diets (in \% dry matter)

\begin{tabular}{lcccc}
\hline Nutrient & \multicolumn{1}{l}{ R1 } & R2 & R3 & R4 \\
\hline Dry matter & 88.38 & 87.73 & 88.25 & 88.31 \\
Crude protein & 14.00 & 13.98 & 14.06 & 14.02 \\
Ash & 4.48 & 4.45 & 4.48 & 4.49 \\
Crude fiber & 12.56 & 11.78 & 12.19 & 12.37 \\
Ether extract & 6.20 & 7.06 & 6.75 & 6.95 \\
Nitrogen-free extract & 62.74 & 62.70 & 62.49 & 62.15 \\
NDICP & 9.51 & 9.95 & 10.76 & 10.89 \\
ADICP & 8.25 & 8.65 & 8.43 & 8.61 \\
NDF & 59.39 & 55.99 & 58.00 & 58.77 \\
ADF & 45.52 & 37.60 & 40.14 & 41.18
\end{tabular}

R1, control TMR silage without BSF larvae; R2, 20\% intact BSF larvae + 80\% TMR silage; R3, $20 \%$ chemically defatted BSF larvae $+80 \%$ TMR silage; R4, $20 \%$ mechanically defatted BSF larvae $+80 \%$ TMR silage

DM, dry matter; ADF, acid detergent fiber; NDF, neutral detergent fiber; ADICP, acid detergent insoluble crude protein; NDICP, neutral detergent insoluble crude protein

using a pressurized fat extractor (Savoire et al., 2013) while chemical fat removal was conducted by using Soxhlet apparatus and hexane as the solvent (Jayanegara et al., 2018). The BSF larvae were included in dietary treatments that consisted of: control TMR silage without BSF larvae (R1), $20 \%$ intact BSF larvae $+80 \%$ TMR silage (R2), $20 \%$ chemically defatted BSF larvae $+80 \%$ TMR silage (R3), and 20\% mechanically defatted BSF larvae $+80 \%$ TMR silage (R4). All materials were mixed homogeneously into $1000 \mathrm{ml}$ lab-scale silos according to the procedure of Kondo et al. (2016). Each dietary treatment was incubated for $30 \mathrm{~d}$ in six replicates. Analyses of proximate and Van Soest, i.e., neutral detergent fiber (NDF) and acid detergent fiber (ADF) were performed (Van Soest et al., 1991) in order to determine the chemical composition of the TMR.

\section{In sacco Incubation Procedure}

Determination of in sacco feed degrada- tion in the rumen at various incubation times was performed according to Ørskov et al. (1980). The study used $7 \mathrm{~cm} \times 11 \mathrm{~cm}$ nylon bags with $60 \mathrm{mi}$ cron pore holes. The dry weight of each nylon bag was $0.5-1 \mathrm{~g}$. Each bag was marked and three bags of feed ingredients containing $2 \mathrm{~mm}$ ground and defatted BSF larvae-based TMR silage were used. Each bag was first dried in the oven at $60^{\circ}$ $\mathrm{C}$ and then filled with $5 \mathrm{~g}$ of the sample, weighed and fastened with rubber. All the nylon bags (containing the samples) were inserted into the rumen at various incubation time intervals.

The incubation was conducted by following a completely randomized design with four dietary treatments and six replications. Samples were put in the rumen for $0,4,12,24,48$ and 72 hours. For the samples at $0 \mathrm{~h}$ only, the samples were not put into the rumen but were washed under running water for $5 \mathrm{~min}$ to remove dissolved particles and then dried at $60^{\circ} \mathrm{C}$ for 24 hours. After incubation, the nylon bags were 
washed with water and then dried at $60^{\circ} \mathrm{C}$ for 24 hours or until the sample weight was stable. The samples were then analysed to determine their chemical composition.

\section{Data Analysis}

Data on nutrient degradation were fitted with the following non-linear regression mode:

$$
p=a+b\left(1-e^{-c t}\right)
$$

where $p$ is degradability at $t$ time (\%), $a$ is dissolved fraction (\%), $b$ is degradable fraction $(\%), c$ is degradation rate constant (\%/hour), $e$ is natural number and $t$ is incubation time (hour). The Neway Excel package program was used to calculate the parameter kinetics of $a, b$ and $c$. All data were analysed using analysis of variance (ANOVA) by according the completely randomized design. The Tukey's test was used to compare the various treatments. Statistical analysis was carried out by using CoStat statistical program version 6.4.

\section{RESULTS AND DISCUSSION}

Table 1 indicates the dietary composition of the TMR. The crude protein (CP) contents in all dietary treatments were relatively the same, at around 14\% DM. Nitrogen-free extract (NFE) contents were also similar, i.e., approximately $62 \%$ in all treatments. The BSF larvae is a potential feed ingredient by providing an alternative protein source and reducing the dependence on soybean meal. In terms of nutritional content, BSF larvae have high CP levels and a balanced composition of amino acids. (Sánchez-Muros et al., 2014; Crosbie et al., 2020). Jayanegara et al. (2017a) stated that BSF larvae have 40-44\% CP content. Apart from the protein, BSF larvae also have high ether extract (18-38.8\% DM) and ash contents $(20-28.4 \% \mathrm{DM})$, reflecting the different diets of insects (Makkar et al., 2014). In terms of their fatty acid composition, BSF larvae contain high levels of saturated fatty acids (40\%), especially lauric acid and palmitic acid, and relatively low levels of unsaturated fatty acids (3.4-
11.6\%) (Spranghers et al., 2017; Jayanegara et al., 2020).

The largest part of the insect's exoskeleton is chitin, a polymer of $\mathrm{N}$-acetylglucosamine (Hahn et al., 2020). BSF larvae were reported to contain chitin between 2.9-14.1\% DM (Ferrer Llagostera et al., 2019; Brigode et al., 2020). Because chitin contains nitrogen groups, it is recovered as NDICP and ADICP as indicated by the higher values of these components in R2, R3 and R4 than that in R1. The increasing age of BSF larvae is accompanied by the development of the exoskeleton, this increases the proportion of chitin per DM unit (Zhu et al., 2016).

The in sacco nutrient degradability of TMR silage containing intact and defatted BSF larvae incubated for 72 hours is presented in Table 2. The lowest DMD was found in R1 compared to all treatments $(\mathrm{p}<0.05)$, while the highest DMD was found in R2 $(p<0.05)$. The highest OMD was found in R2 compared to R1, R3 and R4 ( $<$ 0.05). Further, DMD and OMD kinetics of intact and defatted BSF larvae-based TMR silage incubated for 72 hours are presented in Figure 1. The high chitin content in BSF larvae negatively affects DMD and OMD (Jayanegara et al., 2017a). With regard to protein utilisation, the addition of both intact and defatted BSF larvae to TMR increased the CPD as compared to control $(\mathrm{p}<0.05)$. Apparently the effect of chitin on CPD is similar to its deacetylated derivative, i.e., chitosan. Dietary chitosan addition was reported to elevate DMD and CPD (Gandra et al., 2016; 2018), although some other reports did not find so (Henry et al., 2015; Seankamsorn et al., 2019). The increase of nutrient digestibility of ruminants due to chitin and chitosan is seemed to be related to the change of microbial population structure in the rumen. The compounds decrease the population and activity of protozoa, and subsequently decrease predation of the fauna on rumen bacteria, and finally enhance the bacteria population for degrading substrates (Harahap et al., 2020). Further, the compounds may act like tannins that elevate protein utilisation in the digestive tracts of ruminants (Kondo et al., 2014; Jayanegara et al., 2019). 
Table 2. In sacco Nutrient Degradability of the Experimental Diets Incubated for $72 \mathrm{~h}$

\begin{tabular}{ccccc}
\hline \multirow{2}{*}{ Variable } & \multicolumn{4}{c}{ Treatment } \\
\cline { 2 - 5 } & $\mathrm{R} 1$ & $\mathrm{R} 2$ & $\mathrm{R} 3$ & $\mathrm{R} 4$ \\
\hline $\mathrm{DMD}(\%)$ & $65.9^{\mathrm{c}} \pm 0.79$ & $71.4^{\mathrm{a}} \pm 1.30$ & $69.4^{\mathrm{ab}} \pm 2.37$ & $68.6^{\mathrm{b}} \pm 1.55$ \\
OMD (\%) & $63.9^{\mathrm{b}} \pm 0.59$ & $70.1^{\mathrm{a}} \pm 1.35$ & $68.1^{\mathrm{a}} \pm 2.74$ & $67.2^{\mathrm{a}} \pm 1.67$ \\
CPD (\%) & $71.4^{\mathrm{b}} \pm 1.43$ & $76.4^{\mathrm{a}} \pm 1.43$ & $76.4^{\mathrm{a}} \pm 1.14$ & $74.9^{\mathrm{a}} \pm 1.31$ \\
CFD (\%) & $81.3^{\mathrm{a}} \pm 2.07$ & $80.8^{\mathrm{b}} \pm 1.78$ & $83.5^{\mathrm{a}} \pm 0.88$ & $82.4^{\mathrm{a}} \pm 1.49$
\end{tabular}

\footnotetext{
Means in the same column with varying values superscripts differ significantly $(\mathrm{p}<0.05)$

R1, control TMR silage without BSF larvae; R2, 20\% intact BSF larvae + 80\% TMR silage; R3, $20 \%$ chemically defatted BSF larvae $+80 \%$ TMR silage; R4, 20\% mechanically defatted BSF larvae $+80 \%$ TMR silage

DMD, dry matter degradability; OMD, organic matter degradability; $\mathrm{CPD}$, crude protein degradability; CFD, crude fat degradability
}

Degradation kinetics of $a, b$ and $c$ for DMD, OMD, CPD and CFD in TMR silage containing BSF larvae are presented in Table 3. Besides having a high protein content, intact BSF larvae have a high fat content as well. The high fat content induced low levels of $a, b$ and $c$ parameters of DMD degradation in R2. Defatted
BSF larvae-based TMR silage in R3 and R4 had higher degradability compared to the TMR silage without BSF larvae in R1 ( $\mathrm{p}<0.05)$. In a previous study, Mulianda et al. (2020) confirmed that the overall fat content of BSF larvae could reduce DMD and OMD in the rumen. In the rumen, lipids are converted by lipolysis into glyc-

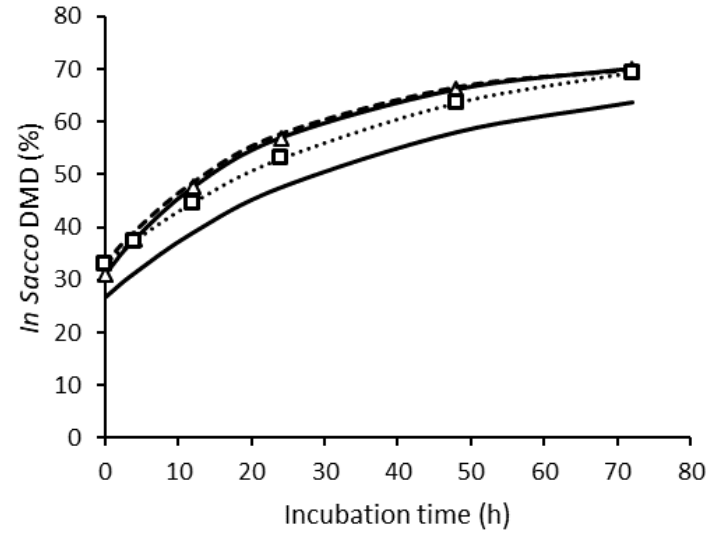

(a)

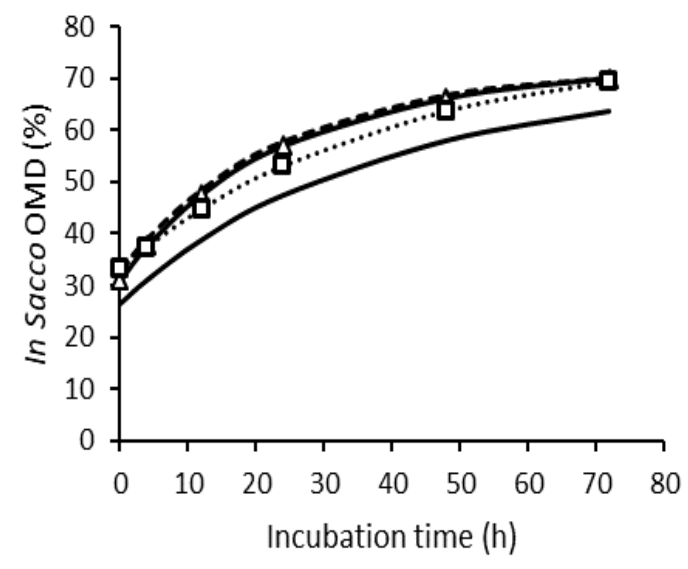

(b)

Figure 1. In sacco (a) dry matter degradability (DMD) and (b) organic matter degradability (OMD) absolute mixed ration (TMR) silage kinetics containing BSF (defatted black soldier fly) larvae. The lowest DMD was found in R1, while the highest DMD was found in R2. The highest OMD was found in R2 among all treatments 
Table 3. In sacco Degradation Kinetics of the Experimental Diets

\begin{tabular}{|c|c|c|c|c|}
\hline \multirow[t]{2}{*}{ Variable } & \multicolumn{4}{|c|}{ Treatment } \\
\hline & R1 & R2 & R3 & $\mathrm{R} 4$ \\
\hline \multicolumn{5}{|c|}{ Dry matter degradation } \\
\hline$a(\%)$ & $25.4^{\mathrm{b}}$ & $31.0^{\mathrm{a}}$ & $33.0^{\mathrm{a}}$ & $33.2^{\mathrm{a}}$ \\
\hline$b(\%)$ & $47.6^{\mathrm{a}}$ & $43.3^{\mathrm{ab}}$ & $39.0^{\mathrm{b}}$ & $41.4^{\mathrm{ab}}$ \\
\hline$c(\% /$ hour $)$ & 2.65 & 3.82 & 4.26 & 2.63 \\
\hline$a+b(\%)$ & 74.2 & 74.3 & 72.0 & 74.7 \\
\hline \multicolumn{5}{|c|}{ Organic matter degradation } \\
\hline$a(\%)$ & $20.3^{\mathrm{b}}$ & $28.2^{\mathrm{a}}$ & $29.8^{\mathrm{a}}$ & $30.2^{\mathrm{a}}$ \\
\hline$b(\%)$ & 49.0 & 44.7 & 41.0 & 45.5 \\
\hline$c(\% /$ hour $)$ & 2.67 & 3.65 & 4.29 & 2.63 \\
\hline$a+b(\%)$ & 70.5 & 72.8 & 70.8 & 75.8 \\
\hline \multicolumn{5}{|c|}{ Crude protein degradation } \\
\hline$a(\%)$ & $24.6^{\mathrm{c}}$ & $29.2^{\mathrm{b}}$ & $31.8^{\mathrm{ab}}$ & $34.0^{\mathrm{a}}$ \\
\hline$b(\%)$ & 51.6 & 49.7 & 46.3 & 50.0 \\
\hline$c(\% /$ hour $)$ & $3.41^{\mathrm{ab}}$ & $4.05^{\mathrm{ab}}$ & $4.93^{\mathrm{a}}$ & $2.49^{b}$ \\
\hline$a+b(\%)$ & $76.5^{\mathrm{b}}$ & $78.9^{\mathrm{ab}}$ & $78.1^{\mathrm{b}}$ & $84.1^{\mathrm{a}}$ \\
\hline \multicolumn{5}{|c|}{ Crude fat degradation } \\
\hline$a(\%)$ & $48.6^{\mathrm{b}}$ & $17.4^{\mathrm{c}}$ & $57.3^{\mathrm{a}}$ & $51.7^{\mathrm{b}}$ \\
\hline$b(\%)$ & $39.7^{\mathrm{b}}$ & $67.9^{\mathrm{a}}$ & $30.9^{\mathrm{c}}$ & $30.5^{\mathrm{c}}$ \\
\hline$c(\% /$ hour $)$ & $2.57^{\mathrm{b}}$ & $4.65^{\mathrm{a}}$ & $3.39^{\mathrm{b}}$ & $5.87^{\mathrm{a}}$ \\
\hline$a+b(\%)$ & $88.4^{\mathrm{a}}$ & $85.2^{\mathrm{ab}}$ & $88.2^{\mathrm{a}}$ & $82.2^{\mathrm{b}}$ \\
\hline
\end{tabular}

Means in the same column with varying values superscripts differ significantly $(\mathrm{p}<0.05)$

R1, control TMR silage without BSF larvae; R2, 20\% intact BSF larvae + 80\% TMR silage; R3, $20 \%$ chemically defatted BSF larvae $+80 \%$ TMR silage; 4 , $20 \%$ mechanically defatted BSF larvae $+80 \%$ TMR silage

$a$, dissolved fraction; $b$, potentially degradable fraction; $c$, degradation rate

erol and fatty acids by certain microbes particularly Anaerovibrio lipolytica (Granja-Salcedo et al., 2017). After lipolysis, unsaturated fatty acids are biohydrogenated to produce fatty acid isomers with high levels of saturation (Dewanckele et al., 2020). In addition, glycerol is fermented to volatile fatty acids especially propionate in the rumen (Syahniar et al., 2016). Furthermore, lipids can reduce enteric methane emissions by decreasing OM fermentation in rumen, reducing the methanogenic activity of archaea, destroying the protozoa in which some methanogens exist in interdependence with ruminal fauna, and be- having as alternative hydrogen absorbers (Knapp et al., 2014; Broucek, 2018).

\section{CONCLUSION}

Inclusion of both intact and defatted BSF larvae into TMR silage up to $20 \%$ DM did not have any adverse effects on nutrient profiles and showed a good nutrient degradation values in the rumen. The larvae may be used to replace, at least partially, the commonly used soybean meal as a protein source in the diets of ruminants. 


\section{ACKNOWLEDGMENTS}

All authors are grateful to the Ministry of Science and Technology of the Republic of Indonesia for providing "Penelitian Dasar Unggulan Perguruan Tinggi (PDUPT)" research grant (contract number 1/E1/KP.PTNBH/2021, year 2021) and BPTBA LIPI for laboratory support.

\section{REFERENCES}

Barragan-Fonseca, K.B., M. Dicke and J.J.A. van Loon. 2017. Nutritional value of the black soldier fly (Hermetia illucens L.) and its suitability as animal feed - a review. J. Insects Food Feed 3(2):105-120.

Biasato, I., I. Ferrocino, S. Dabbou, R. Evangelista, F. Gai, L. Gasco, L. Cocolin, M.T. Capucchio and A. Schiavone. 2020. Black soldier fly and gut health in broiler chickens: Insights into the relationship between cecal microbiota and intestinal mucin composition. J. Anim. Sci. Biotechnol. 11 (1):art. no. 11.

Brigode, C., P. Hobbi, H. Jafari, F. Verwilghen, E. Baeten and A. Shavandi. 2020. Isolation and physicochemical properties of chitin polymer from insect farm side stream as a new source of renewable biopolymer. J. Clean. Prod. 275:art. no. 122924.

Broucek, J. 2018. Options to methane production abatement in ruminants: A review. J. Anim. Plant Sci. 28(2):348-364.

Crosbie, M., C. Zhu, A.K. Shoveller and L.A. Huber. 2020. Standardized ileal digestible amino acids and net energy contents in full fat and defatted black soldier fly larvae meals (Hermetia illucens) fed to growing pigs. Transl. Anim. Sci. 4(3):1-10.

Dewanckele, L., P.G. Toral, B. Vlaeminck and V. Fievez. 2020. Role of rumen biohydrogenation intermediates and rumen microbes in diet-induced milk fat depression: An update. J. Dairy Sci. 103(9):76557681.

Ferrer Llagostera, P., Z. Kallas, L. Reig and D.
Amores de Gea. 2019. The use of insect meal as a sustainable feeding alternative in aquaculture: Current situation, Spanish consumers' perceptions and willingness to pay. J. Clean. Prod. 229:10-21.

Gandra, J.R., C.S. Takiya, E.R. Oliveira, P.G. Paiva, R.H.T.B. de Goes, R.S. Gandra and H.M.C. Araki. 2016. Nutrient digestion, microbial protein synthesis, and blood metabolites of Jersey heifers fed chitosan and whole raw soybeans. Rev. Bras. Zootec. 43:130-137.

Gandra, J.R., C.S. Takiya, T.A. Del Valle, E.R. Oliveira, R.H.T.B. de Goes, R.S. Gandra, J.D.O. Batista and H.M.C. Araki. 2018. Soybean whole-plant ensiled with chitosan and lactic acid bacteria: Microorganism counts, fermentative profile, and total losses. J. Dairy Sci. 101:7871-7880.

Granja-Salcedo, Y.T., V.C. de Souza, A.V.L. Dias, A.S. Gomez-Insuasti, J.D. Messana and T.T. Berchielli. 2017. Diet containing glycerine and soybean oil can reduce ruminal biohydrogenation in Nellore steers. Anim. Feed Sci. Technol. 225:195-204.

Hahn, T., E. Tafi, A. Paul, R. Salvia, P. Falabella and S. Zibek. 2020. Current state of chitin purification and chitosan production from insects. J. Chem. Technol. Biotechnol. 95 (11):2775-2795.

Harahap, R.P., D. Setiawan, Nahrowi, S. Suharti, T. Obitsu and A. Jayanegara. 2020. Enteric methane emissions and rumen fermentation profile treated by dietary chitosan: A meta-analysis of in vitro experiments. Trop. Anim. Sci. J. 43(3):233-239.

Henry, D.D., M. Ruiz-Moreno, F.M. Ciriaco, M. Kohmann, V.R.G. Mercadante, G.C. Lamb and N. DiLorenzo. 2015. Effects of chitosan on nutrient digestibility, methane emissions, and in vitro fermentation in beef cattle. J. Anim. Sci. 93(7):3539-3550.

Jayanegara, A., N. Yantina, B. Novandri, E.B. Laconi, Nahrowi and M. Ridla. 2017a. Evaluation of some insects as potential feed ingredients for ruminants: Chemical composition, in vitro rumen fermentation 
and methane emissions. J. Indonesian Trop. Anim. Agric. 42(4):247-254.

Jayanegara, A., B. Novandri, N. Yantina and M. Ridla. 2017b. Use of black soldier fly larvae (Hermetia illucens) to substitute soybean meal in ruminant diet: an in vitro rumen fermentation study. Vet. World 10 (12):1439-1446.

Jayanegara, A., R.P. Harahap, R.F. Rozi and Nahrowi. 2018. Effects of lipid extraction on nutritive composition of winged bean (Psophocarpus tetragonolobus), rubber seed (Hevea brasiliensis), and tropical almond (Terminalia catappa). Vet.World 11(4):446-451.

Jayanegara, A., T.U.P. Sujarnoko, M. Ridla, M. Kondo and M. Kreuzer. 2019. Silage quality as influenced by concentration and type of tannins present in the material ensiled: A meta-analysis. J. Anim. Physiol. Anim. Nutr. 103(2):456-465.

Jayanegara, A., R. Gustanti, R. Ridwan and Y. Widyastuti. 2020. Fatty acid profiles of some insect oils and their effects on in vitro bovine rumen fermentation and methanogenesis. Ital. J. Anim. Sci. 19 (1):1310-1317.

Knapp, J.R., G.L. Laur, P.A. Vadas, W.P. Weiss and J.M. Tricarico. 2014. Enteric methane in dairy cattle production: Quantifying the opportunities and impact of reducing emissions. J. Dairy Sci. 97(6):3231-3261.

Kondo, M., Y. Hirano, K. Kita, A. Jayanegara and H. Yokota. 2014. Fermentation characteristics, tannin ensiled and in vitro ruminal degradation of green tea and black tea by-products ensiled at different temperatures. Asian Australas. J. Anim. Sci. 27(7):937-945.

Kondo, M., K. Shimizu, A. Jayanegara, T. Mishima, H. Matsui, S. Karita, M. Goto and T. Fujihara. 2016. Changes in nutrient composition and in vitro ruminal fermentation of total mixed ration silage stored at different temperatures and periods. J. Sci. Food Agric. 96:1175-1180.

Makkar, H.P.S., G. Tran, V. Heuzé and P. An- kers. 2014. State-of-theart on use of insects as animal feed. Anim. Feed Sci. Technol. 197:1-33.

Morris, D.L., T.M. Brown-Brandl, K.E. Hales, K.J. Harvatine and P.J. Kononoff. 2020. Effects of high-starch or high-fat diets formulated to be isoenergetic on energy and nitrogen partitioning and utilization in lactating Jersey cows. J. Dairy Sci. 103 (5):4378-4389.

Mulianda, R., R.P. Harahap, E.B. Laconi, M. Ridla and A. Jayanegara. 2020. Nutritional evaluation of total mixed ration silages containing maggot (Hermetia illucens) as ruminant feeds. J. Anim. Health Prod. 8 (3):138-144.

Ørskov, E.R., D.D. Hovell and F. Mould. 1980. The use of the nylon bag technique for the evaluation of feedstuffs. Trop. Anim. Prod. 5(3):195-213.

Sánchez-Muros, M., F. Barroso and F. ManzanoAgugliaro. 2014. Insect meal as renewable source of food for animal feeding: a review. J. Clean. Prod. 65:16-27.

Savoire, R., J. Lanoisellé and E. Vorobiev. 2013. Mechanical continuous oil expression from oilseeds: a review. Food Bioprocess Technol. 6(1):1-16.

Seankamsorn, A., A. Cherdthong and M. Wanapat. 2019. Combining crude glycerin with chitosan can manipulate in vitro ruminal efficiency and inhibit methane synthesis. Animals 10(1):art. no. 37.

Shumo, M., I.M. Osuga and F.M. Khamis. 2019. The nutritive value of black soldier fly larvae reared on common organic waste streams in Kenya. Sci. Rep. 9:art. no. 10110.

Sogari, G., M. Amato, I. Biasato, S. Chiesa and L. Gasco. 2019. The potential role of insects as feed: A multi-perspective review. Animals 9(4):art. no. 119.

Spranghers, T., M. Ottoboni, C. Klootwijk, A. Ovyn, S. Deboosere, B.D.B. Meulenaer, J. Michiels, M. Eeckhout, P. De Clercq and S. De Smet. 2017. Nutritional composition of black soldier fly (Hermetia illucens) 
prepupae reared on different organic waste substrates. J. Sci. Food Agric. 97 (8):2594-2600.

Syahniar, T.M., M. Ridla, A.A.B. Samsudin and A. Jayanegara. 2016. Glycerol as an energy source for ruminants: A meta-analysis of in vitro experiments. Media Peternak. 39(3):189-194.

Van Huis, A. 2013. Potential of insects as food and feed in assuring food security. Ann. Rev. Entomol. 58:563-583.

Van Soest, P.J., J.B. Robertson and B.A. Lewis. 1991. Methods for dietary fiber, neutral detergent fiber and nonstarch polysaccharides in relation to animal nutrition. $\mathrm{J}$ Dairy Sci. 74(10): 3583-3597.

Zhu, K., H. Merzendorfer, W. Zhang, J. Zhang and S. Muthukrishnan. 2016. Biosynthesis, turnover, and functions of chitin in insects. Ann. Rev. Entomol. 61:177-196.

Zotte, A.D., Y. Singh, J. Michiels and M. Cullere. 2019. Black soldier fly (Hermetia illucens) as dietary source for laying quails: Live performance, and egg physico -chemical quality, sensory profile and storage stability. Animals 9(3):art. no. 115. 